\title{
Effect of CSR on Customer Loyalty: Moderating Effect of Authenticity
}

\author{
Kihan Chun ${ }^{1}$ and Wonseok Bang ${ }^{2 *}$ \\ ${ }^{1}$ Department of Business Administration, Gyeongsang National University, 501, \\ Jinju-Daero, Jinju52828, South Korea \\ ${ }^{2}$ Department of Business Administration, Gyeongsang National University, 501, \\ Jinju-Daero, Jinju52828, South Korea \\ ${ }^{1}$ khchung@gnu.ac.kr, ${ }^{2 *}$ bangws@daum.net
}

\begin{abstract}
Corporate social responsibility (CSR) issues have received attention of consumer, communities and policy makert due to importance of CSR. The purpose of this paper is to investigate the effects of CSR (ethical, environmental and well-being CSR) on customer loyalty through brand image and customer trust as well as moderating effect of authenticity. The study proposes that CSR has a positive impact on brand image and customer trust, which influence customer loyalty as well. In addition, the result shows that the moderating effect of authenticity is sinificant.

Therefore, this study highlights the importance of managing CSR for corporate that intends to enhance customer loyalty. Fast food firms must consider how authentic CSR activities in connection with corporate goal are effective and strategic in the era of rising share value.
\end{abstract}

Keywords: CSR, Brand image, Customer trust, Customer loyalty, Authenticity

\section{Introduction}

Today, corporate social responsibility (CSR) is increasingly being recognized by stakeholders, specially consumers and communities, as well as policy maker again due to its importance on ethical, environmental and well-being issues. The latest incident involving the global German automaker company, Volkswagen, now is at the center of a fire storm over its cheating on diesel emissions tests. Volkswagen now seems to be faced with serious image problems because consumers feel betrayed by Volkswagen. Besides, with the emergence of ethical consumerism, consumers have a strong sense of personal responsibility in dealing with climate change and do everything they can to live ethically [1]. Consumers have put more weight on corporate social responcibity than have focused on something technical. Moreover, in 2011, nearly 60\% of Fortune 500 companies published corporate accountability reports and more than one-third of large U.S. companies have voluntarily implemented external certifications for social and environmental standards [2].

Corporate with taking social responsibility such as ethical, environmental will be able to compete with others [3]. That's why companies recognize that CSR has become important business factor. Defra (2011) states that there is no one clear reason why people eat organic food but important factors are nutrition value, health reasons, environmental concerns and animal welfare [4]. So, customers consider not only engaging in an environmentally friendly behavior and healthy food, but also try to purchase products or service of CSR related corporate. McDonald also highlights three Es, ethics,

* Corresponding Author 
environmental and economic viability, and good source ingredients for menu items.

Few studies on CSR-related for food service firms, specially in Asia countries, has been conducted. Therefore, more researches are required in this direction. The purpose of this study is not only to analyze the relationship among CSR (ethical, environmental, well-being CSR), brand image, customer trust, customer loyalty, but also to employ the moderating effect of authenticity for fast food corporate such as McDonald, Lotteria, Mom's touch etc.

\section{Literature Review}

\subsection{CSR and Brand Image}

The concept of CSR indicates how companies through different types of activities consider and manage their influence on society and various stakeholders, especially customers; in regards to environmental, social, and welfare issues [5]. CSR in the food industry addresses food safety, well-being food, animal welfare, environmental protection. Thus, this study defines CSR activities based on three dimensions; ethical responsibility based on Carroll's concept, environmental responsibility and well-being responsibility that are related to core factors for fast food restaurants.

Meanwhile, Kotler and Keller (1991) defined brand image as a set of beliefs and opposed that it is the total of consumer's evaluation to brand attribute [6]. Brand image is a set of associations that customers perceived over time as resulting in direct or indirect experience for brand [7]. This study defines brand image as the consumer's thoughts and feelings about a corporate brand because corporate image and brand image in consumer memory are the same.

Customers perceive brands in regards to their being socially and environmentally responsible. A 1997 Cone study shows that 76 percent of consumers are prepared to switch to brands that seem concerned about the community [8].

H1: CSR has a positive influence on brand image.

\subsection{CSR and Customer Trust}

The results of a survey of CEOs at the Business Roundtable Institute for Corporate Ethics (2004) indicate that one of top issues in corporate ethics is related to regaining public trust [9]. Consumers have been shown to reward companies that engage in CSR with interest, loyalty and trust [10]. There will be a positive relationship between customer perception of CSR and customer trust. Thus, the following relationship is hypothesized:

H2: CSR has a positive influence on customer trust.

\subsection{Relationships Among Brand Image, Customer Trust, Customer Loyalty}

Brand image or brand association has been identified as a major driver of trust and loyalty [11-12]. Trust is regarded as a key determinant of customer loyalty [13-14]. Essentially, customer trust serves as a principal component of enduring long-turm relationship between customers and service firms [15]. In service industries, it appears that when a customer trusts a brand and service quality, customers are likely to build a positive behavioral attitude toward the brand [16]. Furthermore, with regard to organic products, the study focused on customer trust, which is only one of the possible factors driving purchasing decisions [17].

H3: Brand image has a positive influence on customer trust. 
H4: Brand image has a positive influence on customer loyalty.

H5: Customer trust has a positive influence on customer loyalty.

\subsection{Moderating Effect of Authenticity}

The consumers consider that the authenticity of company activities is important. Authenticity and CSR when combined as interconnected parts can impact corporate success [18]. In addition, stakeholder perceptions of authenticity are critical determinants of CSR initiatives success [19]. Gao and Mattila (2014) showed that consumers are more satisfied when they perceive a firm's CSR motive as public-serving, comparing to selfserving [20]. Another study showed that inauthentic CSR can be harmful for the corporation meanwhile authentic CSR can strengthen the corporation [21].

H6: Authenticity will be moderate the impact of CSR on brand image.

H7: Authenticity will be moderate the impact of CSR on customer trust.

\section{The Research}

The research is designed to confirm the relationships among CSR, brand image, customer trust and loyalty, and the moderating effect of authenticity between CSR and brand image, CSR and customer trust.

\subsection{Research Model}

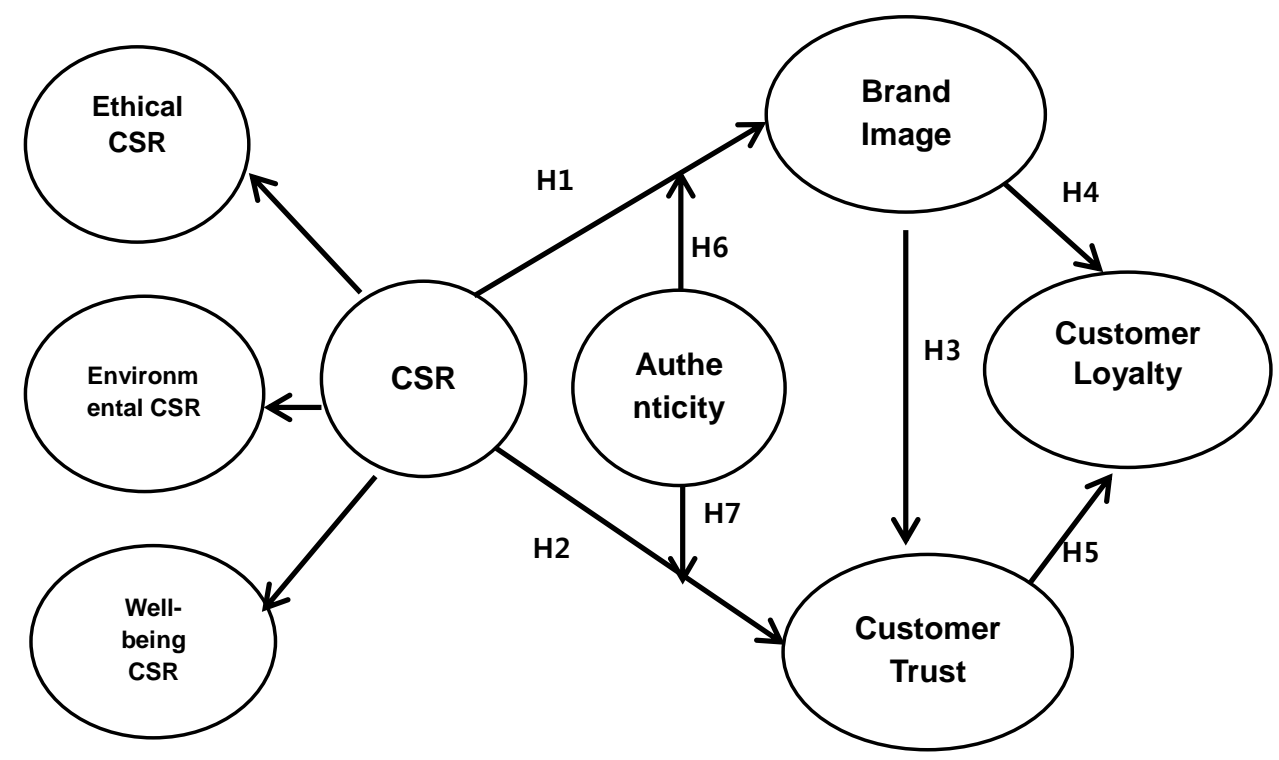

Figure 1. Research Model

\subsection{Research Methodology}

3.2.1. Measures: Based on the previous literature, we selected measurement items that we deemed appropriate for the present study. We utilized measurement items used in the existing literature to create a sound basis for specifying the constructs to be measured. The participants were asked to respond using a seven-point Likert scale ranging from 1 (strongly disagree) to 7 (strongly agree). We use each three item of ethical CSR based on Caroll's study, environmental CSR and well-being CSR, three items of brand image, three items of customer trust, and three items of customer loyalty.

3.2.2. The Sample: The survey was completed by 220 people inculding most university students in Jinju city. 24 of them were determined to be unusable. Examination of 
demographic characteristics with 196 indicates the respondents to be female (41.8 percent) and male (57.7 percent).

3.2.3. Assessment of the Measures: The measurement model was evaluated for overall fit with the data, reliability, and convergent and discriminant validity. Before testing the hypotheses, reliability and validity tests were performed to further refine measurements after pre-test samples. The properties of all of the items were located as reflective measures on their respective factors and evaluated via comprehensive confirmatory factor analysis (CFA) using AMOS 18.0. The overall measurement model fit indices indicate that the comprehensive confirmatory factor model fits the data well (chi-square 193.762, df 142, p 0:000, CFI 0:982, TLI 0:976, GFI 0:915, AGFI 0.874, RMR 0.067, RMSEA $0.043)$.

The results of confirmatory factor analysis(CFA) is shown in Table 1. Cronbach's alpha was used to assess the internal consistency of the constructs. The range of the Cronbach alpha coefficients for each construct was high range from 0.751 (ethical CSR) to 0.930 (customer trust). All the alpha coefficients were over the cut-off point of 0.7, suggesting reliablity and a high reliability was deemed satisfactory. T-value and average variance extracted (AVE) were employed to test convergent validity. The $\mathrm{T}$ - values of each measure were acceptable (all exceeded 0.7) and the AVEs for each construct were good (all exceeded 0.50). Overall, the measurement model suggested good convergent validity, as shown in Table 1.

In addition, as presented in Table 2, the AVE values were greater than the squared cofficients. As a result, we were able to verify the discriminant validity of all measurements used.

Table 1. Results of Confirmatory Factor Analysis (CFA)

\begin{tabular}{|c|c|c|c|c|c|c|c|c|}
\hline Construct & Items & $\begin{array}{c}\text { Std. } \\
\text { Estimate }\end{array}$ & S.E. & t-value & $P$ & Cronbach' a & C. R. & AVE \\
\hline \multirow{3}{*}{$\begin{array}{l}\text { Ethical } \\
\text { CSR }\end{array}$} & EC6 & 0.885 & - & - & - & \multirow{3}{*}{0.751} & \multirow{3}{*}{0.883} & \multirow{3}{*}{0.718} \\
\hline & EC5 & 0.714 & .093 & 8.785 & $\star \star \star *$ & & & \\
\hline & EC1 & 0.926 & .095 & 8.223 & $* * *$ & & & \\
\hline \multirow{4}{*}{$\begin{array}{l}\text { Environ- } \\
\text { mental } \\
\text { CSR }\end{array}$} & EVC7 & 0.794 & - & & - & \multirow{4}{*}{0.902} & \multirow{4}{*}{0.908} & \multirow{4}{*}{0.769} \\
\hline & EVC6 & 0.969 & .079 & 15.504 & $* * *$ & & & \\
\hline & EVC5 & 0.860 & .093 & 8.785 & $\star * *$ & & & \\
\hline & WC7 & 0.907 & - & - & - & & & \\
\hline \multirow{4}{*}{$\begin{array}{l}\text { Well-being } \\
\text { CSR }\end{array}$} & WC6 & 0.943 & .050 & 19.867 & $* * *$ & \multirow{2}{*}{0.889} & \multirow{2}{*}{0.897} & \multirow{2}{*}{0.748} \\
\hline & WC4 & 0.731 & .064 & 13.369 & $\star * *$ & & & \\
\hline & T5 & 0.817 & .054 & 15.770 & $\star \star *$ & \multirow{5}{*}{0.930} & \multirow{5}{*}{0.849} & \multirow{5}{*}{0.651} \\
\hline & T4 & 0.820 & .058 & 15.783 & $\star * *$ & & & \\
\hline \multirow{3}{*}{$\begin{array}{l}\text { Customer } \\
\text { Trust }\end{array}$} & T3 & 0.897 & - & - & - & & & \\
\hline & T2 & 0.865 & .060 & 17.353 & $\star * *$ & & & \\
\hline & $\mathrm{T} 1$ & 0.749 & .055 & 13.704 & $* * *$ & & & \\
\hline \multirow{4}{*}{$\begin{array}{l}\text { Brand } \\
\text { Image }\end{array}$} & $\mathrm{BI} 5$ & 0.784 & - & - & - & \multirow{4}{*}{0.848} & \multirow{4}{*}{0.951} & \multirow{4}{*}{0.631} \\
\hline & $\mathrm{BI} 6$ & 0.754 & .081 & 11.062 & $\star \star \star *$ & & & \\
\hline & $\mathrm{Bl} 8$ & 0.844 & .089 & 12.383 & $\star \star * *$ & & & \\
\hline & L5 & 0.822 & .107 & 12.180 & $\star \star * *$ & & & \\
\hline \multirow[t]{2}{*}{ Loyalty } & L3 & 0.886 & .094 & 13.183 & $\star * *$ & \multirow[t]{2}{*}{0.865} & \multirow[t]{2}{*}{0.871} & \multirow[t]{2}{*}{0.689} \\
\hline & L2 & 0.780 & - & - & - & & & \\
\hline
\end{tabular}

$\mathrm{x}^{2}(\mathrm{df})=193.762(142), \mathrm{p}=0.000, \mathrm{CMIN} / \mathrm{DF}=1.365 \mathrm{GFI}=0.915, \mathrm{AGFI}=0.874, \mathrm{IFI}=0.983, \mathrm{TLI}=0.976$, $\mathrm{CFI}=0.982, \mathrm{RMR}=0.067, \mathrm{RMSEA}=0.043$ 
The results of correlations identified is shown in Table 2 . The discriminant validity of all measurements used can be verified.

Table 2. Results of Correlation Analysis

\begin{tabular}{ccccccc}
\hline Vaiables & F1 & F2 & F3 & F4 & F5 & F6 \\
\hline F1 & 0.718 & & & & & \\
F2 & 0.185 & 0.769 & & & & \\
F3 & 0.199 & 0.350 & 0.748 & & & \\
F4 & 0.298 & 0.054 & 0.091 & 0.651 & & \\
F5 & 0.271 & 0.133 & 0.119 & 0.582 & 0.631 & \\
F6 & 0.225 & 0.069 & 0.077 & 0.614 & 0.620 & 0.689 \\
\hline
\end{tabular}

F1:Ethical CSR, F2:Environmental CSR, F3:Well-being CSR, F4:Brand image, F5: Customer trust, F6:Customer loyalty

CSR has been modeled as a second-order factor in this study. The dimesions of CSR are ethical CSR, environmental CSR, well-being CSR, among which the environmental CSR has the strongest dimension on CSR as seen in Table 3.

Table 3. CFA of Second-Order Measurement Model

\begin{tabular}{|c|c|c|c|c|c|}
\hline Dimensions & $\begin{array}{l}\text { Sub- } \\
\text { Paths }\end{array}$ & Elements & Std. C. & S.E. & C.R. \\
\hline Ethical CSR & $\leftarrow$ & \multirow{3}{*}{ CSR } & 0.633 & - & - \\
\hline $\begin{array}{l}\text { Environmental } \\
\text { CSR }\end{array}$ & $\leftarrow$ & & 0.780 & 0.208 & 5.530 \\
\hline $\begin{array}{l}\text { Well-being } \\
\text { CSR }\end{array}$ & $\leftarrow$ & & 0.775 & 0.222 & 5.743 \\
\hline EC6 & $\leftarrow$ & \multirow{3}{*}{ Ethical CSR } & 0.808 & - & - \\
\hline EC5 & $\leftarrow$ & & 0.769 & 0.108 & 8.712 \\
\hline EC1 & $\leftarrow$ & & 0.581 & 0.73 & 7.228 \\
\hline EVC7 & $\leftarrow$ & \multirow{3}{*}{$\begin{array}{c}\text { Environmental } \\
\text { CSR }\end{array}$} & 0.800 & - & - \\
\hline EVC6 & $\leftarrow$ & & 0.961 & 0.78 & 15.501 \\
\hline EVC5 & $\leftarrow$ & & 0.861 & 0.73 & 14.058 \\
\hline WC7 & $\leftarrow$ & \multirow{3}{*}{$\begin{array}{l}\text { Well-being } \\
\text { CSR }\end{array}$} & 0.911 & - & - \\
\hline WC6 & $\leftarrow$ & & 0.936 & 0.52 & 18.954 \\
\hline WC4 & $\leftarrow$ & & 0.734 & 0.067 & 12.773 \\
\hline
\end{tabular}

\section{Findings}

The testing of the hypotheses in this study adopted a structural equation modeling(SEM) designed to simultaneously examine the structural relationships among the proposed constructs. Structural equation modeling (SEM) was conducted to test the hypothesized relationships. So, $\mathrm{H} 1-\mathrm{H} 5$ are tested with structural equation modeling using in AMOS 18.

The results of path analysis for hypothesis verification is shown as Table 4 . The model fit indices support the fit of the full structural model to the data $\left(\chi^{2}(\mathrm{df})=217.565(151)\right.$, $\mathrm{p}=0.000, \mathrm{GFI}=0.908, \mathrm{AGFI}=0.872$, IFI=0.907, TLI=0.971, CFI=0.977, RMR=0.068, RMSEA=0.048). The estimates were consistent with the proposed direction of the hypothesized paths, and all hypotheses $(\mathrm{H} 1, \mathrm{H} 2, \mathrm{H} 3, \mathrm{H} 4$, and $\mathrm{H} 5)$ were supported. 
Table 4. Results of Path Analysis for Hypothesis Verification

\begin{tabular}{|c|c|c|c|c|c|}
\hline Hypothesis & Path & $\begin{array}{c}\text { Path } \\
\text { coefficient }\end{array}$ & t-value & $\begin{array}{c}\mathrm{p}- \\
\text { value }\end{array}$ & Results \\
\hline $\mathrm{H} 1$ & CSR $\rightarrow$ Brand Image & 0.323 & 4.045 & $\star \star \star *$ & Supported \\
\hline $\mathrm{H} 2$ & CSR $\rightarrow$ Customer Trust & 0.245 & 3.368 & $\star \star \star *$ & Supported \\
\hline $\mathrm{H} 3$ & $\begin{array}{l}\text { Brand Image } \rightarrow \\
\text { Customer Trust }\end{array}$ & 0.692 & 9.321 & $* * *$ & Supported \\
\hline $\mathrm{H} 4$ & $\begin{array}{l}\text { Brand Image } \rightarrow \\
\text { Customer Loyalty }\end{array}$ & 0.415 & 4.121 & $* * *$ & Supported \\
\hline H5 & $\begin{array}{l}\text { Customer Trust } \rightarrow \\
\text { Customer Loyalty }\end{array}$ & 0.481 & 4.968 & $* * *$ & Supported \\
\hline
\end{tabular}

The results of path analysis for hypothesis verification shown as Figure 2 are significant $(\mathrm{p}<0.05)$.

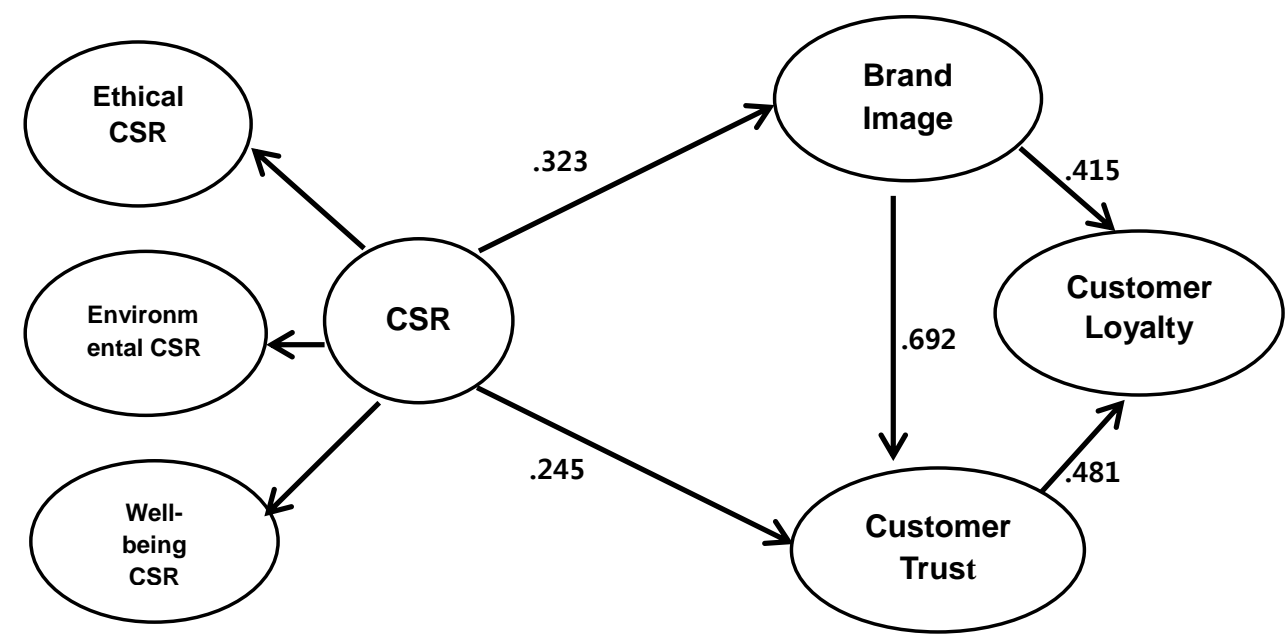

Figure 2. Main Effects Test

Table 5 shows that the relationships between CSR and brand image, CSR and customer trust are moderated by authenticity. The moderating role of authenticity is significant for both CSR-brand image and CSR-customer trust relationship as seen in Table 5.

Table 5. Moderating Effects of Authenticity

\begin{tabular}{|c|c|c|c|c|c|c|c|}
\hline \multirow[b]{2}{*}{ Path } & \multirow[b]{2}{*}{$\begin{array}{c}\text { Independent } \\
\text { Variable }\end{array}$} & \multirow[b]{2}{*}{$\begin{array}{l}\text { Dependent } \\
\text { Variable }\end{array}$} & \multicolumn{2}{|c|}{ Std. Estimate } & \multirow[b]{2}{*}{$\begin{array}{l}\text { Free } \\
\text { Model }\end{array}$} & \multirow[b]{2}{*}{$\begin{array}{l}\text { Constrained } \\
\text { Model }\end{array}$} & \multirow{2}{*}{$\begin{array}{c}\Delta \chi^{2} \\
(\mathrm{df}=1)\end{array}$} \\
\hline & & & $\underset{(n=124)}{\text { High }}$ & $\begin{array}{l}\text { Low } \\
(n=71)\end{array}$ & & & \\
\hline H6 & CSR & $\begin{array}{l}\text { Brand } \\
\text { Image }\end{array}$ & $\begin{array}{c}0.464 \\
(3.103)\end{array}$ & $\begin{array}{c}0.747 \\
(3.482)\end{array}$ & & 616.781 & 4.212 \\
\hline $\mathrm{H} 7$ & CSR & $\begin{array}{l}\text { Customer } \\
\text { Trust }\end{array}$ & $\begin{array}{c}0.028 \\
(0.263)\end{array}$ & $\begin{array}{c}0.560 \\
(1.803)\end{array}$ & 612.569 & 616.159 & 3.59 \\
\hline
\end{tabular}

\section{Conclusions}

The results reveal that CSR has a positive effect on brand image and customer trust, as well as each brand image and customer trust positively influences customer loyalty. In addition, the moderating effect of authenticity is significant. This study demonstrates that authentic CSR plays a role of a contributor to customer loyalty through brand image and customer trust. 
This paper from a theoretical standpoint is one of the first to examine the effects of CSR on brand image and customer trust for fast food restaurant by using the ethical, environmental and well-being CSR as the sub-dimensions of CSR. Second, authenticity in CSR is one of the important factors to practice CSR [22]. In the vain of management, results of the study also provide managerial some implications. First, customer's perception of authentic CSR initiatives results in positive attitudes about the company. First, fast food firms must consider not only how authentic CSR activities in connection with corporate goal are effective and strategical, but also making the restaurant managers understand the importance of each of these elements. Second, managers and executives of restaurant may want to evaluate how efficient and effective their systems are in implementing CSR initiatives. Therefore, as managers and executives of restrurants recognize that the authenticity is a crucial aspect of successful CSR, they need to develop reasonable expectations of benefits that can be generated from such CSR initiatives.

A limitation is that respondents is necessary to vary the responses. In the future, additional research is needed to investigate comparing foreign brand to local brand and CSR communication as the extra variable.

\section{References}

[1] D. B. Lauritsen and J. K. Perks, "The influence of interactive, non-interactive, implicit and explicit CSR communication on young adults", perception of UK supermarkets'corporate brand image and reputation, Corporate Communications, An International Journal, vol. 20, no. 2, (2015), pp. 178-195.

[2] M. Kitzmueller and J. Shimshack, "Economic perspectives on corporate social responsibility", Journal of Economic Literature, vol. 50, no. 1, (2012), pp. 51-84.

[3] J. S. Oh, J. I. Shin and K. H.Chung, "The Effect Relationship among CSR, Corporate Image, Customer Satisfaction, and Customer Loyalty: Focused on Chinese Case", Korea Association of Business Education., vol. 28, no. 5, (2013), pp.197-220.

[4] A. Defra, "Department for Environment, Food and Rural Affairs", Guidance on Reporting Greenhouse Gas Removals and Emissions from Domestic Woodland Creation, (2011).

[5] A. Blombäck, and C. Scandelius, "Corporate heritage in CSR communication: a meansto responsible brand image? Corporate Communications", An International Journal, vol. 18, no. 3, (2013), pp. 362-382.

[6] P. Kotler and K. L.Keller, "Marketing Management", Person Prentice Hall, (2009).

[7] J. M Baker and J. S.Hart, "The Marketing Book”, Elsevier Ltd, (2008), pp. 315.

[8] R.Cone, "Cause Related Marketing Trends Report", (1997).

[9] C. Fombrun and C. Foss, "Business ethics: Corporate responses to scandal corporate Reputation", Review, vol. 7, no. 3, (2004), pp. 284-288.

[10] N. Nguyen and A. Lelerc, "The effect of service employees competence on financial institutions image: benevolence as a moderator variable", Journal of Services Marketing, (2011), vol. 25, no. 5, pp. 349-360.

[11] B. Busacca and S.Castaldo, "Brand knowledge, brand trust and consumer response: a conceptual framework", Paper presented at the second Work-shop on Trust Within and Between Organizations, Amsterdam, (2003).

[12] K. Phan and G. N. Hantous, "Managing brand associations to drive customers' trust and loyalty in Vietnamese banking", International Journal of Bank Marketing, vol. 31, no. 6, (2013), pp. 456-480.

[13] R. M. Morgan and S. D. Hunt, "The commitment-trust theory of relationship marketing", Journal of Marketing, vol. 58, (1994), pp. 20-38.

[14] E. Garbarino and M. S. Johnson, "The different roles of satisfaction, trust, and commitment in customer relationships", Journal of Marketing, vol. 63, (1999), pp. 70-87.

[15] L. D. Molm, N. Takahashi and G. Peterson, "Risk and trust in social exchange: an experimental test of classical proposition”, American Journal of Sociology, vol. 105, no. 5, (2000), pp. 1396-1427.

[16] N. Nguyen and A. Leclerc, "The effect of service employees competence on financial institutions image: benevolence as a moderator variable", Journal of Services Marketing, vol. 25, no. 5, (2011), pp. 349-609.

[17] S. Pivato, N. Misani and A.Tencati, "The impact of corporate social responsibility on consumer trust: the case of organic food", Business Ethics: A European Review, vol. 17, no. 1, (2008), pp. 3-12.

[18] S. Meghan, "Community Prosperity Student Research Award Program", (2015).

[19] L. McShane and P. Cunningham, "To thine own self be true? Employees' judgements of the authenticity of their organization's corporate social responsibility program", Journal of Bus Ethics, vol. 108, (2012), pp. 81-100.

[20] Y. X. Gao and A. S. Mattila, "Improving Consumer Satisfaction in Green Hotels: The Roles of Perceived Warmth, Perceived Competence and CSR Motive", International Journal of Hospitality Management,vol. 42, (2014), pp. 20-31. 
[21] L. McShane and P.Cunningham, "To thine own self be true? Employees judgments of the authenticity of their organization's corporate social responsibility program”, Journal of business ethics, vol. 108, no. 1, (2012), pp. 81-100.

[22] W. S. Bang, "Building Customer Loyalty through CSR,:Moderating Effect of Authenticity", Advanced Science and Technology Letters, vol. 114, (2015), pp. 101-105.

\section{Authors}

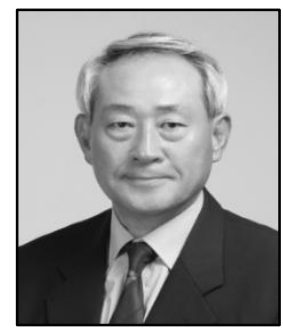

Ki-Han Chung, he is a Professor of Department of Business Administration at Gyeongsang National University, Jinju, South Korea. He received his Ph. D. in Management from Pusan National University, South Korea. His current research interests include marketing channel, market orientation, internal marketing, internet marketing, and service marketing. He has published papers in journals such as Journal of Korea Distribution and Management, Korea Logistics Review, Asia Pacific Journal of Marketing and Logistics, International Journal of Business and information, Korean Journal of Tourism Research, The Journal of internet Electronic Commerce Research, The Academy of Customer Satisfaction Management, Journal of the Korea Entrepreneurship, Journal of Industrial Economics and Business, and International Journal of Information Management.

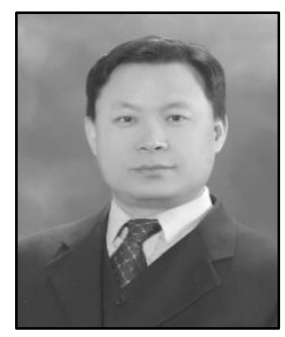

Wonseok Bang, he is a Candidate for $\mathrm{Ph}$. D. of Department of Business Administration at Gyeongsang National University, Jinju, South Korea. He received his Master in Management from Seogang University, South Korea, His current research interests internal marketing, service marketing and internet marketing. 